\title{
Parasite specificity in Podarcis bocagei and $P$. carbonelli (Lacertidae) from NW Portugal: a host-parasite history
}

\author{
Vicente Roca* \\ Departament de Zoologia, Facultat de Ciències Biològiques, Universitat de València, Dr. Moliner 50, 46100 \\ Burjassot, Spain. \\ *Correspondence: Phone: +34 963544606, Fax: +34 963543049, E-mail: Vicente.roca@uv.es
}

Received: 20 June 2014; returned for review: 4 December 2014; accepted 12 December 2014.

Host parasite specificity is related to several factors including the type of life cycle of the parasite, the habitat occupied by both parasites and hosts, and the food habits of the hosts. In this work, gastrointestinal helminths in two congeneric lacertid lizards, Podarcis bocagei and Podarcis carbonelli living in sintopy, have been analysed. Out of four helminth species found, three of them, the trematode Brachylaima sp., the cestode Oochoristica gallica and the nematode Skrjabinelazia hoffmanni, have indirect life cycles while the nematode Spauligodon carbonelli has a direct life cycle. Heteroxenous helminths showed low host specificity whereas $S$. carbonelli may be placed at an intermediate position in a continuum of the degree of specificity.

Key words: host-parasite relationships; Iberian Peninsula; lizards; parasites.

Especificidad parasitaria en Podarcis bocagei y P. carbonelli del NO de Portugal: una historia de parásitos y hospedadores. La especificidad parasitaria está relacionada con diversos factores entre los que se incluyen el tipo de ciclo vital del parásito, el hábitat que ocupan parásito y hospedador, o la estrategia alimentaria de este último. Se analizaron los hospedadores Podarcis bocagei y Podarcis carbonelli (Lacertidae) que habitan un área de sintopía estricta y se estudiaron sus helmintos gastrointestinales. De las cuatro especies de helmintos detectadas, tres de ellas, el trematodo Brachylaima sp., el cestodo Oochoristica gallica y el nematodo Skrjabinelazia hoffmanni, tienen ciclos vitales indirectos mientras que el nematodo Spauligodon carbonelli presenta un ciclo directo. Los helmintos de ciclos heteroxenos mostraron una especificidad baja mientras que $S$. carbonelli ocupa una posición intermedia en un continuo de la especificidad parasitaria.

Key words: lagartijas; parásitos; Península Ibérica; relaciones parásito-hospedador.

The concept of co-evolution between parasites and hosts is based on the fact that the gradual host-parasite adaptation has been adjusting over evolutionary time in mutual gene interaction to get a balanced relationship (CoMbes, 1995; MARtínez-Fernández \& Cordero del CampilLO, 2007). Host specificity is defined as the extent to which a parasite taxon is restricted in the number of host species used at a given stage in the life cycle (Poulin, 1998). Highly host-specific parasites are restricted to one host species (extreme stenoxeny) and specificity declines as the number of suitable host species increases (eurixeny) (Poulin, 1998). To understand why some 
parasites are highly host specific and others are not, it is firstly necessary understand how parasites and hosts have coevolved since the origin of their association (Poulin, loc. cit.). Specificity is related to diverse conditions, as life cycle of the parasite, ecological factors, or physiological characteristics of parasites and hosts, among others, although its molecular bases are still poorly known (Ortega-Mora \& Rojo-VÁzQuez, 2007).

Lacertid lizards Podarcis bocagei (Seoane, 1884) and P. carbonelli PérezMellado, 1981 are suitable for the study of host-parasite specificity because: (i) both are considered paraphyletic species (Lima et al., 2008), and (ii) show a peculiar geographical distribution in Douro littoral region (NW Portugal) including a strictly syntopic area (CARRETERo et al., 2002).

In this study I have analysed the gastrointestinal helminth communities for both hosts in order to know the type and degree of specificity of the different helminth species found.

Eighty seven specimens of $P$. bocagei and 117 of $P$. carbonelli were caught by noose and by hand in Espinho and Granja (UTM $10 \times 10 \mathrm{~km}$ squares, 29T NF24 and NF34). Captures were made in April and Septem-

Table 1: Prevalence of infection of the helminths found in each host.

\begin{tabular}{lcc}
\hline Helminth species & $\begin{array}{c}\text { P. bocagei } \\
(\mathbf{N}=87)\end{array}$ & $\begin{array}{c}\text { P. carbonelli } \\
\text { (N = 117) }\end{array}$ \\
\hline Brachylaima sp. & $1.2 \%$ & $1.7 \%$ \\
Oochoristica gallica & $6.9 \%$ & $2.6 \%$ \\
Spauligodon carbonelli & $1.2 \%$ & - \\
Skrjabinelazia hoffmanni & $6.9 \%$ & $4.3 \%$ \\
\hline
\end{tabular}

ber 2001, and January and August 2002. The searched region is a narrow sandy area consisting in humid dunes covered by psammophilic vegetation, in which both host species are strictly syntopic (CARretero et al., 2002). Lizards were immediately transported to the laboratory, humanely sacrificed with an overdose of chloroform, and analysed for gastrointestinal helminths, which were removed, washed, fixed and mounted according to standard parasitological techniques (GALdón, 2007). Helminths were identified as accurate as possible according adequate bibliography.

Four helminthic species were found (Fig. 1), one trematode (Brachylaima sp. metacercariae), one cestode (Oochoristica gallica) and two nematodes (Spauligodon carbonelli and Skrjabinelazia hoffmanni). Three of these species were common to both hosts, and $S$. carbonelli was found in P. bocagei but not in $P$. carbonelli. Table 1 shows their prevalence of infection in each host.

Although Butcher \& Grove (2005) suggested that the Australian shingleback lizard species (Tiliqua rugosa) may be a definitive hosts for Brachylaima cribbi, the presence of metacercariae (larval forms) of Brachylaima sp. in both Iberian hosts in study may be considered as accidental parasitism. This is considered when a parasite reaches a wrong host in which it is unable to complete its development. As reptiles are usually not definitive hosts for these trematodes, the presence of metacercariae of Brachylaima spp. in some Iberian lizards (see Roca \& Hornero, 1994) is probably due to the ingestion of some terrestrial snails, which are second intermediate hosts (GonZÁLEZ-Moreno, 2002). 

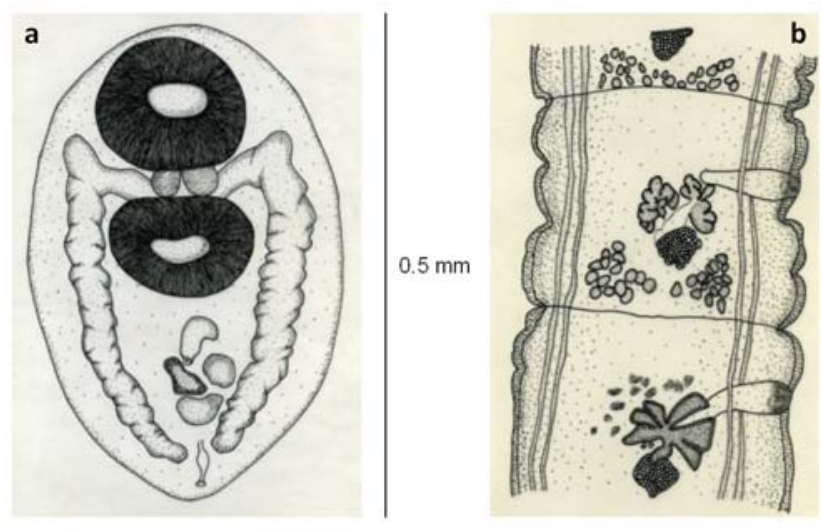

Figure 1: Parasites found in Podarcis lizards. (a) Brachylaima sp. metacercariae from P. bocagei. (b) Oochoristica gallica from $P$. carbonelli, mature proglotids. (c) Spauligodon carbonelli from $P$. carbonelli: ơ caudal end of body, ventral view. (d) Skrjabinelazia hoffmanni from $P$. bocagei: ơ caudal end ventro-lateral view.

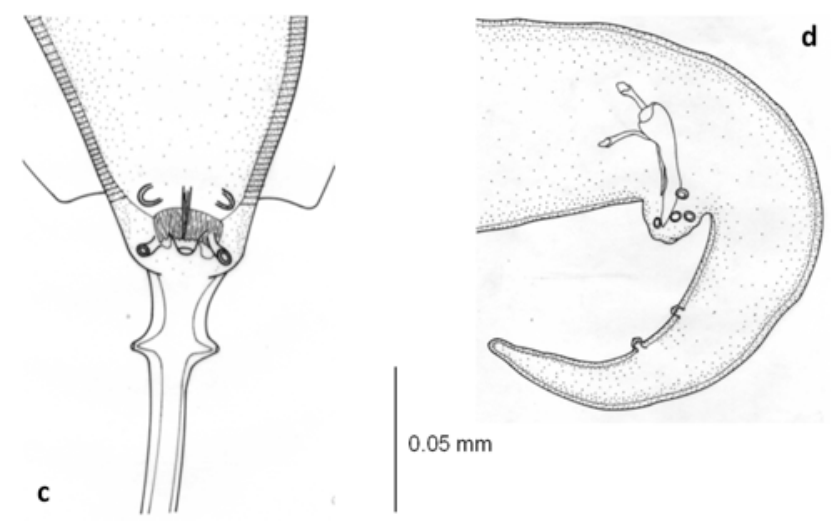

The nematode $S$. hoffmanni is a generalist species (sensu EdwARds \& Bush, 1989) that has been recorded in some genera of Palaearctic lacertid lizards, as Podarcis, Darevskia and Lacerta (GARcíA-Adell \& RoCA, 1988; Roca et al., 1989, 1990; RocA \& Hornero, 1994; Biserkov \& Kostadinova, 1998; Yildirimham et al., 2011; V. Roca et al., unpublished data). Also the cestode O. gallica is a generalist helminth species since it has been recorded in some lizards of the genera Podarcis, Psammodromus and Iberolacerta (GARCía-Adell, 1987; García-Adell \& RoCA, 1988; Roca et al., 1989; RocA \& Hornero, 1994). As the nematode S. carbonelli has been only recorded in the lizards Podarcis muralis, P. carbonelli and P. hispani- ca from the Iberian Peninsula (García-Adell \& Roca, 1988; Roca et al., 1989; Galdón et al., 2006), it may be considered a Podarcis specialist. Skrjabinelazia hoffmanni and O. gallica would be close to the end of the low specificity (eurixeny) and far from the end of the high specificity (estenoxeny), in a continuum of the degree of specificity, whereas $S$. carbonelli would be located at an intermediate position between the two extremes (see references above).

Brachylaima sp., O. gallica and S. hoffman$n i$ have indirect life cycles, and $S$. carbonelli has a direct life cycle. Probably, O. gallica has a diheteroxenic life cycle in which some terrestrial arthropod is involved as intermediate host (some coleopteran in- 
sects and crustacean isopods have been recorded in the case of other species belonging to the genus Oochoristica, GARCíAAdell, 1987). In the case of species of the genus Skrjabinelazia, CHABAud et al. (1988) and Roca et al. (1990) also pointed out a diheteroxenic life cycle in which a coprophagous insect would be the intermediate host. As larval forms of Skrjabinelazia spp. do not suffer any change in those insects, they should be considered paratenic hosts (Chabaud et al., 1988).

Since heteroxenic helminths infect both hosts, it seems that the area inhabited by the studied lizards is suitable for arthropods and gastropods which are intermediate hosts. Ecological factors favour the encounter and facilitates the flow of the life cycle of those parasites and so they show an ecological host specificity (OrTEgAMora \& Rojo-VÁzquez, 2007). Since both hosts show similar eating behaviour (strict carnivores, RocA et al., 2006), an ethological specificity should also be considered (Ortega-Mora \& Rojo-Vázquez, loc. cit.). These two types of specificity do not need a long contact time in the evolution of both parasite and host, and so they fall close to the extreme of eurixeny in a continuum of the degree of specificity.

The more interesting helminth species regarding the relationships with their hosts is S. carbonelli. Its life cycle is direct, which means that the host lizards are infested through accidental ingestion of eggs that are associated with the substrate or adhered to the cloaca region of their hosts (Roca et al., 2006). So, why is the parasite present in $P$. bocagei but not in $P$. carbonelli? Related to the biotic and abiotic conditions in the area of sintopy where the hosts were studied, the chances of contact with the infective eggs of S. carbonelli are the same for both lizards. Therefore, are ethological conditions determining the presence of the parasite in a host but not in the other? RoCA et al. (2006) pointed out that both host species are parasitized by S. carbonelli in other areas of NW Portugal and suggested that variation in the prevalence of infection of both hosts is due to local environmental conditions rather than to ethological differences between the two species, or to host specificity. However, this does not explain the absence of this nematode in $P$. carbonelli in the syntopic area.

Is it relevant to consider a type of phylogenetic specificity that implies the union over prolonged periods of host-parasite interspecific contact, in the course of their evolution? It does not seem appropriate to refer to host specificity sensu stricto since $S$. carbonelli has been recorded in several Podarcis species in the Iberian Peninsula. However, it is noteworthy the absence of this nematode in the endemic lacertid lizards of the Balearic archipelago, Podarcis pityusensis and $P$. lilfordi, in which S. carbonelli is apparently replaced by the congeneric S. cabrerae (Roca \& Hornero, 1994). It should be considered the possibility of a common ancestor of both species of Spauligodon and a speciation of this genus parallel to the speciation of the ancestor that resulted in the current Balearic Podarcis (Alcover, 1988). From this point of view, it is pertinent to consider a presumable phylogenetic relationship of the nematodes S. carbonelli and S. cabrerae regarding the phylogenetic relationship of hosts of Podarcis group in the Iberian Peninsula and the Balearic Islands. 
Jorge et al. (2011) used molecular methods to show that the different species of lizards of the genus Gallotia in the Canary Islands were colonized by two independent Spauligodon lineages. This led to the description of two different species of this genus, S. atlanticus from the islands of Lanzarote and Fuerteventura and S. occidentalis from the western islands (Jorge et al., 2013). Thus, it would be appropriate in this kind of studies to concretize the phylogenetic relationships and the possible coevolution between Ibero-Balearic nematodes of the genus Spauligodon and hosts of Podarcis group.

\section{Acknowledgement}

This study was partially funded by the projects POCTI/BSE/45664/2002 and OCI/ BIA-BDE/55865/2004 of Fundação para a Ciência e a Tecnologia, FCT (Portugal). Collecting permits were provided by Instituto de Conservação da Natureza, ICN (Portugal). Thanks to B. Fráguas, D.J. Harris, R. Pereira, C. Soares and P. Sousa for help with fieldwork. An anonymous referee helped to improve the English language and the quality of the manuscript.

\section{REFERENCES}

Alcover, J.A. (1988). Las faunas preneolíticas de las islas mediterráneas. Mundo Científico 80: 504-517.

Biserkov, V. \& Kostadinova, A. (1998). Intestinal helminth communities in the green lizard Lacerta viridis from Bulgaria. Journal of Helminthology 72: 267-271.

Butcher, A.R. \& Grove, D.I. (2005). Second intermediate host land snails and definitive host animals of Brachylaima cribbi in Southern Australia. Parasite 12: 31-37.
Carretero, M.A.; Sa Sousa, P.; Barbosa, D.; Harris, D.J. \& Pinho, C. (2002). Sintopía estricta entre Podarcis bocagei y P. carbonelli. Boletín de la Asociación Herpetológica Española 13: 20-24.

Combes, C. (1995). Interactions Durables. Écologie et Évolution du Parasitisme. Masson, Paris, France.

Chabaud, A.G.; Bain, O. \& Poinar, G.O., Jr. (1988). Skrjabinelazia galliardi (Nematoda: Seuratoidea): compléments morphologiques et cycle biologique. Annales de Parasitologie Humaine et Comparée 63: 278-284.

Edwards, D.D. \& Bush, A.O. (1989). Helminth communities in avocets: Importance of compound community. Journal of Parasitology 98: 439-445.

Galdón, M.A. (2007). Estudio Parasitológico de Podarcis bocagei y Podarcis carbonelli (Sauria: Lacertidae) del Noroeste de Portugal. Tesis Doctoral, Universitat de València, Burjassot, Spain.

Galdón, M.A.; Roca, V.; Barbosa, D. \& CarreTERo, M.A. (2006). Intestinal helminth communities of Podarcis bocagei and Podarcis carbonelli (Sauria: Lacertidae) in NW Portugal. Helminthologia 43: 37-41.

García-Adell, G. (1987). Helmintofauna de Algunas Especies de Reptiles de los Pirineos Ibéricos. Tesis de Licenciatura, Universitat de València, Burjassot, Spain.

García-Adell, G. \& Roca, V. (1988). Helmintofauna de lacértidos de los Pirineos centrales ibéricos. Revista Ibérica de Parasitología 48:257-267.

GonzÁlez-Moreno, O. (2002). Brachylaima. Contribución al Conocimiento de la Bionomía de Digénidos de la Familia Brachylaimidae Joyeux et Foley, 1930, en el Delta del Llobregat. Tesis Doctoral, Universitat de Barcelona, Barcelona, Spain.

Jorge, F.; Roca, V.; Perera, A.; Harris, D.J. \& CARretero, M.A. (2011). A phylogenetic assessment of the colonisation patterns in Spauligodon atlanticus Astasio-Arbiza et al., 1987 (Nematoda: Oxyurida: Pharyngodoni- 
dae), a parasite of lizards of the genus Gallotia Boulenger: no simple answers. Systematic Parasitology 80: 53-66.

Jorge, F.; Perera, A.; Carretero, M.A.; Harris, D.J. \& RocA, V. (2013). Cryptic species unveiled: the case of the nematode Spauligodon atlanticus. Journal of Zoological Systematics and Evolutionary Research 51: 187-202.

Lima, A.; Pinho, C.; Carretero, M.A. \& Harris, D.J. (2008). Mitochondrial DNA variability within Podarcis morphotype 2: more cryptic variation?, In 6th Symposium on the Lacertids of the Mediterranean Basin, Book of Abstracts. University of the Aegean - Prefectural Authority of Lesvos - Societas Hellenica Herpetologica, Lesvos, Greece, p. 35.

Martínez-Fernández, A.R. \& Cordero del Campillo, M. (2007). El parasitismo y otras asociaciones biológicas. Parásitos y hospedadores, In M. Cordero del Campillo \& F.A. Rojo-Vázquez (eds.) Parasitología General. McGraw-Hill, Madrid, Spain, pp. 22-38.

Ortega-Mora, L.M. \& Rojo-VÁzquez, F.A. (2007). Relaciones parásito-hospedado, In: M. Cordero del Campillo \& F.A. RojoVázquez (eds.) Parasitología General. McGraw-Hill, Madrid, Spain, pp. 39-48.

Poulin, R. (1998). Evolutionary Ecology of Parasites. Chapman \& Hall, London, UK.

Roca, V. \& Hornero, M.J. (1994). Helminth infracommunities of Podarcis pityusensis and Podarcis lilfordi (Sauria: Lacertidae) from the Balearic Islands (western Mediterranean Basin). Canadian Journal of Zoology 72: 658 -664 .

Roca, V.; López-Balaguer, E. \& Hornero, M.J. (1989). Helmintofauna de Podarcis hispanica (Steindachner, 1870) y Podarcis bocagei (Seoane, 1884) (Reptilia: Lacertidae) en el cuadrante noroccidental de la Península Ibérica. Revista Ibérica de Parasitología 49: 127-135.

Roca, V.; López-Balaguer, E.; Hornero, M.J. \& Ferragut, M.V. (1990). Skrjabinelazia hoffmanni Li, 1934 (Nematoda, Seuratidae), parásito de reptiles lacértidos de la Península Ibérica. Boletín de la Real Sociedad Española de Historia Natural (Sección Biología) 86: 125132.

Roca, V.; Carretero,M.A.; Marques, A.; BarBosA, D. \& Galdón, M.A. (2006). Relationships between helminth communities and host traits in Podarcis bocagei and Podarcis carbonelli from NW Portugal. Italian Journal of Zoology 73:213-217.

Yildirimham, H.S.; Bursey, C.R. \& Altunel, F.N. (2011). Helminth parasites of the Balkan Green lizard Lacerta trilineata Bedriaga, 1886, from Bursa, Turkey. Turkish Journal of Zoology 35: 519-535. 